\title{
Le Jour de Dieu - Der Tag Gottes
}

5. Symposium Strasbourg, Tübingen, Uppsala. 11.-13. September 2006 in Uppsala Hrsg. v. Anders Hultgard u. Stig Norin

[The Day of God. 5th Symposium Strasbourg, Tübingen, Uppsala 11-13 September 2006 in Uppsala.]

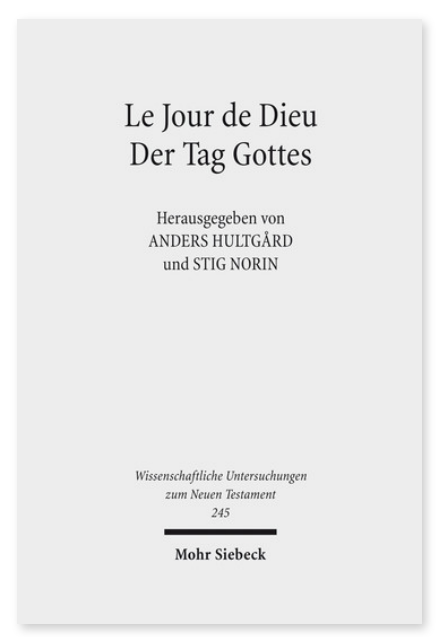

2009. VIII, 252 Seiten. WUNT I 245

ISBN 978-3-16-151534-7

DOI 10.1628/978-3-16-151534-7

eBook PDF 89,00€

ISBN 978-3-16-150068-8

Leinen $89,00 €$
Veröffentlicht auf Französisch.

This book contains the papers presented at the fifth symposium held in Uppsala by the three theological faculties of Strasbourg, Tübingen and Uppsala. The subject of this symposium was »The Day of God. "This term generally has an eschatological meaning, but can also be interpreted differently, as the article on ancient Egyptian religion shows. The topics discussed cover a long period of time, from the ancient Egyptian period to the Scandinavian Middle Ages. Although the articles focus on Judaism and Christianity, they also deal with problems and ideas in Zoroastrianism and in Egyptian religion.

Anders Hultgard ist Professor emeritus für Religionsgeschichte, insbes. Indoeuropäische Religionen an der Universität Uppsala.

Stig Norin ist Professor für alttestamentliche Exegese an der Theologischen Fakultät der Universität Uppsala.

Jetzt bestellen:

https://mohrsiebeck.com/buch/le-jour-de-dieu-der-tag-gottes-9783161515347?no_cache=1

order@mohrsiebeck.com

Telefon: +49 (0)7071-923-17

Telefax: +49 (0)7071-51104 